\title{
Use of BCG as an immunostimulant in the surgical treatment of carcinoma of lung: a five-year follow-up report
}

\author{
F. RONALD EDWARDS AND FRANCIS WHITWELL \\ From the Cardio-thoracic Surgical Centre, Broadgreen Hospital, Liverpool L14 $3 L B$
}

Edwards, F. R., and Whitwell, F. (1978). Thorax, 33, 250-252. Use of BCG as an immunostimulant in the surgical treatment of carcinoma of lung: a five-year follow-up report. Sixty consecutive surviving patients treated with subdermal BCG $\left(5 \times 10^{6}\right.$ organisms $)$ have been followed up for five years after resection of lung carcinoma. A control group of the previous 60 consecutive surviving patients not treated with BCG was similarly studied. We found no statistical evidence that the administration of BCG by the method described influenced the five-year survival rate, nor has any effective action upon involved lymph nodes or small metastases been demonstrated.

In 1974 we published (Edwards and Whitwell, 1974) an interim report on a series of 120 cases of resection for carcinoma of the lung operated upon by one surgeon. Sixty consecutive patients who survived the operation received BCG as a postoperative immunostimulant, and their survival was compared with that of the previous 60 consecutive surviving patients who were used as controls.

The method of administering BCG was by subdermal injection of $0.5 \mathrm{ml}$ of BCG (Glaxo) $\left(5 \times 10^{6}\right.$ organisms) in the deltoid region. This produced a local reaction, $2-3 \mathrm{~cm}$ diameter, which usually broke down to produce a series of sinuses or an ulcer, which persisted for four to six months.

All 120 cases have been followed up through the clinical registry of the Liverpool Regional Cancer Organisation to determine the period of survival. It has been possible to establish the date of death or five-year survival in all patients. In this age group it is difficult to establish the exact cause of death as most patients died at home and few necropsies were permitted. It is reasonable to assume that the death of some of these patients was due to some other cause than carcinomatosis, and that the number of such patients in each group was approximately the same, as the age groups were comparable (Table 1).

Some data of the control and BCG groups are shown in Table 2.
Table 1 Average age and cell types of tumours in the control and BCG-treated groups

\begin{tabular}{|c|c|c|c|c|}
\hline \multirow{2}{*}{$\begin{array}{l}\text { Cell } \\
\text { Type }\end{array}$} & \multicolumn{2}{|c|}{ Control } & \multicolumn{2}{|c|}{$B C G$} \\
\hline & No. & $\begin{array}{l}\text { Average age } \\
(y r)\end{array}$ & No. & $\begin{array}{l}\text { Average age } \\
(y r)\end{array}$ \\
\hline Squamous & 30 & $59 \cdot 3$ & 35 & $59 \cdot 6$ \\
\hline Oat-cell & 9 & $59 \cdot 7$ & 8 & $56 \cdot 3$ \\
\hline Adenocarcinoma & 13 & $57 \cdot 1$ & 12 & $61 \cdot 2$ \\
\hline Carcinoma simplex & 3 & $60 \cdot 0$ & 1 & 70 \\
\hline Mixed & 3 & $67 \cdot 0$ & 4 & $60 \cdot 7$ \\
\hline Clear-cell & 1 & $67 \cdot 0$ & - & - \\
\hline Adenomatosis & 1 & $63 \cdot 0$ & - & - \\
\hline Total & 60 & $59 \cdot 5$ & 60 & $59 \cdot 9$ \\
\hline
\end{tabular}

Table 2 Basic data of the control and BCG groups

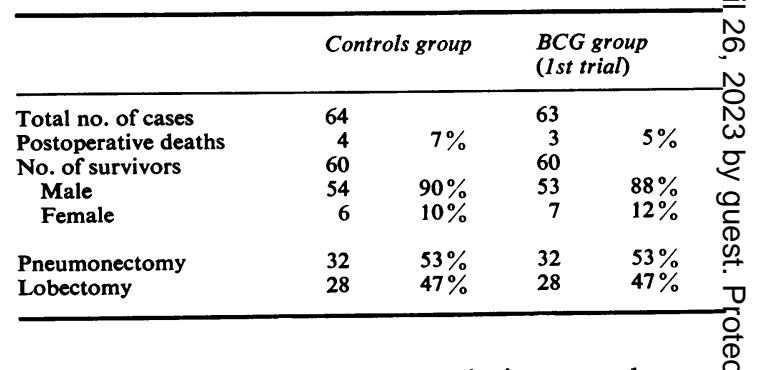

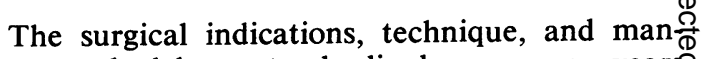
agement had been standardised over many years and were not knowingly different in detail in the two groups. All macroscopic disease was remove 8 
Table 3 Survival of control $(C)$ and $B C G$ groups

\begin{tabular}{|c|c|c|c|c|c|c|c|c|c|c|c|c|}
\hline \multirow[t]{2}{*}{ Cell type } & \multicolumn{2}{|c|}{ Total No. } & \multicolumn{2}{|c|}{2 years } & \multicolumn{2}{|c|}{3 years } & \multicolumn{2}{|c|}{4 years } & \multicolumn{4}{|c|}{5 years } \\
\hline & $C$ & $B C G$ & $C$ & $B C G$ & $C$ & $B C G$ & $C$ & $B C G$ & $C$ & $\%$ & $B C G$ & $\%$ \\
\hline Squamous & 30 & 35 & 15 & 22 & 12 & 17 & 9 & 13 & 9 & 30 & 12 & 34 \\
\hline Oat-cell & 9 & 8 & 1 & 4 & - & 2 & - & 2 & - & - & 2 & 25 \\
\hline Adenocarcinoma & 13 & 12 & 4 & 4 & 4 & 3 & 4 & 3 & 3 & 23 & 3 & 25 \\
\hline Carcinoma simplex & 3 & 1 & 1 & 1 & - & 1 & - & 1 & 一 & - & 1 & 100 \\
\hline Mixed & 3 & 4 & 1 & - & - & - & - & - & - & - & - & - \\
\hline Clear-cell & 1 & - & - & - & - & - & - & - & - & - & - & - \\
\hline Adenomatosis & 1 & - & 1 & - & 1 & - & - & - & - & - & - & - \\
\hline Total & 60 & 60 & 23 & 31 & 17 & 23 & 13 & 19 & 12 & & 18 & \\
\hline$\%$ Survival & & & 38 & 52 & 28 & 38 & 22 & 32 & & 20 & & 30 \\
\hline
\end{tabular}

in each case. Except for 10 specimens, which were reported elsewhere, all resected material in both groups was submitted to the same pathologist, who determined the histological type of tumour and the lymph node involvement. All histological reports referred to the removed tumour and not to bronchoscopic biopsy specimens. No patient in either group received treatment with radiotherapy or chemotherapy except to relieve symptoms from metastases when indicated.

\section{Survival rate}

The overall survival rates of the control and BCG series are shown in Table 3.

The five-year survival rate of $20 \%$ for the particular control series selected was lower than the usually accepted figure $(25.5 \%$ in the previous 180 surviving patients operated upon by the same surgeon), but the figures for the squamous-cell and adenocarcinoma survivals were virtually the same in the control and BCG series.

The type of resection did not materially influence the five-year survival (Table 4).

In view of the possibility that BCG may have a more specific stimulant action upon macrophages and lymphocytes in invaded residual lymph nodes, the five-year survival of patients with and without histologically involved lymph nodes was compared

Table 4 Type of operation and five-year survival

\begin{tabular}{|c|c|c|c|c|}
\hline \multirow[t]{2}{*}{ Histology } & \multicolumn{2}{|c|}{ Lobectomy } & \multicolumn{2}{|c|}{ Pneumonectomy } \\
\hline & Control & $B C G$ & Control & $B C G$ \\
\hline Squamous & $4 / 11$ & $8 / 17$ & $5 / 19$ & $4 / 18$ \\
\hline Oat-cell & $0 / 2$ & $0 / 1$ & $0 / 7$ & $2 / 7$ \\
\hline Adenocarcinoma & $3 / 11$ & $3 / 7$ & $0 / 2$ & $0 / 5$ \\
\hline Carcinoma simplex & $0 / 1$ & $1 / 1$ & $0 / 2$ & - \\
\hline Mixed & $0 / 1$ & $0 / 2$ & $0 / 2$ & $0 / 2$ \\
\hline Clear-cell & $0 / 1$ & - & - & - \\
\hline Adenomatosis & $0 / 1$ & - & - & - \\
\hline Total & $7 / 28$ & $12 / 28$ & $5 / 32$ & $6 / 32$ \\
\hline$\%$ Survival & 25 & 39 & 16 & 19 \\
\hline
\end{tabular}

(Table 5). These figures are analysed into the different histological types in Table 6. No statistical difference is apparent in these two groups.

The survival for five years of two patients out of eight with oat-cell carcinoma after receiving BCG is of interest but of no significance when these small numbers are involved.

Table 5 Five-year survival with and without involved nodes

\begin{tabular}{lllll}
\hline Group & \multicolumn{2}{l}{ Nodes } & & \\
\cline { 2 - 5 } & Positive & & \multicolumn{2}{l}{ Negative } \\
\hline $\begin{array}{l}\text { Control } \\
\text { (60 cases) }\end{array}$ & $2 / 30$ & $7 \%$ & $10 / 30$ & $33 \%$ \\
$\begin{array}{l}\text { BCG } \\
(60 \text { cases })\end{array}$ & $3 / 28$ & $11 \%$ & $15 / 32$ & $47 \%$ \\
\hline
\end{tabular}

\section{Conclusion}

Using the method of BCG inoculation that we have adopted, no evidence has been obtained that the overall survival rate of patients undergoing resection for lung carcinoma has been significantly prolonged, nor has any action upon residual involved lymph nodes or small latent metastases been demonstrated.

This investigation has been supported by the Liverpool University Cancer Research Committee, and we are grateful to the Liverpool Regional Cancer Organisation for the use of their clinical registry, and to Mr. L. Freedman, statistical officer, for undertaking the statistical assessment.

\section{Reference}

Edwards, F. R., and Whitwell, F. (1974). Use of BCG as an immunostimulant in the surgical treatment of carcinoma of the lung. Thorax, 29, 654-658.

Requests for reprints to: F. Ronald Edwards, FRCS, Cardio-thoracic Surgical Centre, Broadgreen Hospital, Liverpool L14 3LB. 


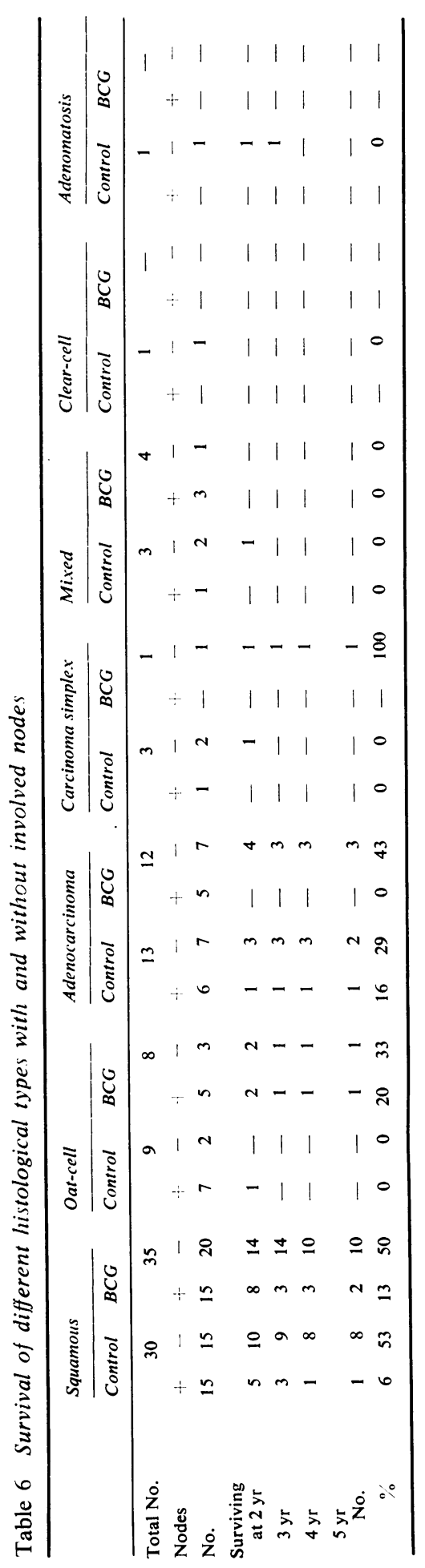

